\title{
The Effect of Training Education, Motivation and Knowledge Sharing on Employee Performance
}

\author{
${ }^{1}$ C. Catur Widayati, ${ }^{2}$ Agus Arijanto, ${ }^{3}$ Purnamawati Helen Widjaja, \\ ${ }^{4}$ Magito, ${ }^{5}$ Wahyu Anggraini \\ 1,2,4,5 Faculty of Economics and Business, Universitas Mercu Buana Jakarta, Indonesia \\ Email: christinewijaya73@yahoo.co.id/catur.widayati@mercubuana.ac.id \\ ${ }^{3}$ Faculty of Economics and Business, Tarumanagara University, Indonesia \\ Email: purnamawatiw@fe.untar.ac.id
}

ABSTRACT

Indonesia

This study aims to determine the effect of education and training, motivation, and knowledge sharing on employee performance at PT Telkom Akses BSD. This study was conducted on 127 respondents using a quantitative descriptive approach with the nonprobability sampling method of the Slovin formula. The data analysis used is the Component or Variance Based Structural Equation Model and processed with the Partial Least Square (Smart-PLS) version 3.0 PLS program. The results of this study indicate that Education and Training, Motivation and Knowledge Sharing have a simultaneous and partial effect on employee performance at PT Telkom Akses BSD because it has a T-Statistic value >1.96 and a P-value <0.05. Knowledge Sharing has the greatest influence with the amount of influence of 0.372

\section{Keywords: Education and Training, Motivation and Knowledge Sharing, Employee Performance}

\section{PRELIMINARY}

Humans are an important resource in achieving organizational goals that have different characteristics from other resources. Humans are said to be an important resource because no matter how sophisticated the existing technology is, humans are the main actors in the technology itself. Human resources (HR) in a company or organization are essential for running the wheels of a company or organization, whatever form and nature they are engaged in in the trade or service sector, will always try to achieve the previously set goals effectively and efficiently. (Heriyanto and Hidayati, 2016).

Organizations must realize that to achieve the stated goals, many factors influence it, one of the factors that determine the success of an organization is the quality of human resources (Pituringsih, 2019). It is human resources who design and apply all the designs that are the targets of the organization, given the important role of human resource managers in an organization to survive in a climate of unlimited free competition, the role of human resource management is no longer the responsibility of employees or employees, terapai is the responsibility of the organization (Shen \& Zhang, 2019).

In the era of globalization, human resource problems must be managed properly because the main role of wellmanaged human resources can determine the existence, effectiveness, and efficiency of organizations including organizations in government. The existence referred to refers to and refers to the ability of the organization to be able to continue to provide services in the form of services to all stakeholders. Effectiveness is the ability of an organization to be able to achieve its goals and carry out the duties and functions and roles of the organization according to the provisions, while the efficiency of the organization's ability to achieve its goals and to carry out its functions and roles by using optimal resources So, without human resources government agencies or organizations can't continue to exist and be able to carry out their duties and functions and roles.

According to Indriapati, et al., (2020), the performance of an employee in carrying out his duties and work is inseparable from his motivation. The motivation of an employee to work is usually shown by activities in work that are oriented towards organizational goals. The era of globalization of information and communication technology which is running very fast must be accompanied by the creativity and capability of employees in carrying out their duties in the organization so that education and training of human resources are very important to be carried out to achieve organizational goals.

Various factors can affect employee performance, these factors include Education and Training, Motivation, and Knowledge Sharing. Several experts stated that the education and training program is one of the most important human resource activities in facing various company challenges, both today and in the future. Education and training is a teaching and learning process using certain techniques and methods, to improve the skills and work abilities of a person (employee or group of people). Education and training (training) is a learning process that involves the acquisition of skills, concepts, rules, or attitudes to improve employee performance. In the following, expert opinions on education and training will be described. About the effect of education and training on performance, there are 3 (three) approaches to performance measurement, one of which is the behavioral approach, namely by measuring: education and training, feedback, presentation skills, response to customer complaints. 
One of the ways that can be done to improve employee performance is through employee development, namely by conducting education and training Sedarmayanti (2016). Employee performance is not just information for promotion or salary determination for the company. However, how can companies motivate employees and develop a plan to improve performance decline can be avoided (Elizar \& Tanjung, 2018)?

In Selong Research (2019) education and training is a process to improve the theoretical, conceptual, and moral skills of employees. In other words, people who receive education and training in a planned manner are more likely to be able to work skillfully when compared to employees who do not attend education and training. Education and training seek to develop the intellectual abilities and personalities of employees. Therefore, every organization that wants to develop must pay attention to employee education and training so that it can affect improving employee performance.

Apart from training, motivation can also affect employee performance. Motivation or motivation means giving motives, arising motives or things that give rise to encouragement, or circumstances that give rise to encouragement. Motivation can also be defined as a factor that encourages people to act in a certain way. According to Hasibuan (2016), Motivation is what causes, channels, and supports human behavior, so that they are willing to work hard and enthusiastically to achieve optimal work results. In this case, it is employees, to take action, encouraging is intended to encourage employees so that they are excited and can achieve results as desired by these people.

Motivation is indispensable in employees because motivation affects employee performance in achieving company goals (Amalia and Fakhri, 2016). Many external and internal factors in the work environment influence motivation so that it has a high and low impact on employee performance. Therefore, motivation does not arise only because of economic needs in the form of money, but in other forms such as respect, appreciation, and good and harmonious relationships by colleagues. So employees get satisfaction and are motivated in doing their work by fulfilling extrinsic and intrinsic needs.

In general, high performance is associated with high motivation. Conversely, low motivation is associated with low performance. Someone's performance is sometimes not related to the competence they have, because there are self and work environment factors that affect performance. High performance is a function and interaction between motivation, competence, and opportunities for supporting resources. The influence of motivation on performance can be seen in that this employee performance variable is operationally measured by using four indicators adopted, one of which is the company's ability to motivate employees to improve the efficient use of human resources. Self-actualization is included in the performance.
Apart from training and motivation, there is one more thing that affects employee performance, namely knowledge sharing. According to Rumijati (2020), knowledge sharing also has an important role for organizations. Knowledge sharing can improve individual competencies and abilities by sharing information and knowledge. According to Pio \& Kaparang (2017), the main reason for implementing knowledge management is the low performance of employees when doing group work. This is the opposite when compared to the performance of individual employees. Before the implementation of knowledge management, each employee was not an inspiration to other employees if there was some kind of deadlock in the work. Therefore, it is necessary to have a culture of knowledge sharing between employees so that information about developments from the outside and from within can be spread thoroughly to all parts and levels in PT Telkom Akses BSD so that the knowledge is possessed by each employee is not buried within each other. employees. With the existence of a culture of knowledge sharing like this, PT Telkom Akses BSD can quickly find out about the latest developments and can adapt to environmental changes that are felt to be getting faster. Where the final goal of the three variables is performance improvement. According to Siagian (2010), performance is basically what employees do so that it affects how much they contribute to the agency or organization, including the quality services that are served.

The phenomenon that occurs at PT Telkom Akses BSD is that there are still employees who do not have the right skills in their field of work, and knowledge sharing among employees is not optimal, as well as lack of motivation from the employees themselves to learn and improve their skills. Based on this, to describe the performance of employees in the Ministry of Communication and Information, a temporary presurvey was conducted of 24 employees in the Treasury Department.

From the results of the pre-survey, it was found that the performance of the employees of PT Telkom Akses BSD was still not optimal, it can be seen from the fact that not all employees came to work early, employees could not reach the predetermined targets in work and work also could not be completed on time. the time. In addition, knowledge sharing, motivation, and training for employees at PT Telkom Akses BSD are also still problematic. This can be seen from the results of the pre-survey to 24 employees of PT Telkom Akses BSD randomly.

The results of the pre-survey show that knowledge sharing, motivation, and training programs for employees of PT Telkom Akses BSD are still not optimal. In terms of knowledge sharing, there has not been a process of knowledge sharing between employees at PT Telkom Akses BSD and among other employees of the bureau. In terms of motivation, employees feel less motivated at work, this is due to the lack of concern of the leader for the potential of employees and their 
success in completing work. Then in terms of training education shows that the training program implemented or attended by several employees at PT Telkom Akses BSD is still felt to be less than optimal to increase the potential and performance of employees. Several previous studies examined the effect of Education and Training, Motivation, and Knowledge Sharing on Employee Performance.

Regarding research on the effect of Education and Training on employee performance, there is a positive and significant influence between the two. This was stated by researchers conducted by Sakti and Mulyadi (2015), Saputra, and Pakpahan's research (2014). Then, for the next variable, namely motivation, in general, the results of research regarding motivation on employee performance are that there is a positive and significant influence between the two. This is stated by the results of research conducted by Hidayat (2020); Wibowo (2019); Marifa et al., (2018); Setiawan (2015); Jatmiko (2015); Arfan (2013) states that there is the same result that motivation has a positive and significant effect on employee performance. Different results can be obtained from research conducted by Muogbo, (2013). which states that there is no significant relationship or influence between intrinsic motivation and employee performance and research from Puspitasari (2014) that motivation harms employee performance.

And the last is the knowledge sharing variable, in general, the results of research regarding knowledge sharing on employee performance are that there is a positive and significant influence between the two. On the other hand, several previous studies conducted by Andria and Trisyulianti (2016), Zaeid et al. (2012), Kuzu and Özilhan (2014), Anggapraja (2016), and Yousef Obeidat et al., (2017) state that knowledge sharing has a significant positive effect on performance. Other researchers were also carried out by Memah and Gerson (2017), Vrizka, V., \& Silvianita, A. (2016), who stated that there was the same result that knowledge sharing had a positive and significant effect on employee performance.

Based on the description that has been explained in the background above, the authors can identify the problems that arise, namely: (1) Do Education and Training affect performance? (2) Does motivation affect performance? (3) Does Knowledge Sharing affect performance?

The objectives of this study were: (a) To determine and analyze the effect of training education on employee performance; (b) To determine and analyze the influence of motivation on employee performance; (c) To determine and analyze the influence of Knowledge Sharing on employee performance.

\section{THEORETICAL REVIEW}

\section{Education and Training}

Education and training as an effort to develop human resources, especially to develop intellectual abilities and human personality. Therefore, to obtain maximum results in employee development, education and training programs are needed following job analysis so that employees know the objectives of education and training that they are carrying out. The education and training program is the design of a system in the process of changing a person's attitude and behavior as well as increasing or acquiring skills (skills) in the context of maturity through teaching and training efforts. The training program is a reflection of what learning experiences participants should draw based on the objectives to be achieved (Daryanto and Bintoro in Rozi's research, \& Anggraini, 2019).

According to Ningrum (2013), education and training are the tools to match duties and jobs with the abilities, skills, or abilities and expertise of each employee and is an effort to improve employee performance as an introduction to certain jobs for those concerned. Whether or not employee performance will affect the stability of an organization in achieving the goals set. The training given to employees will encourage employees to work harder, this is because employees who already know the duties and responsibilities well will try to achieve a higher level of work morale.

Meanwhile, according to Syahputra \& Jufrizen (2019), education and training are an effort to develop human resources, especially to develop intellectual abilities and human personality. Therefore, to obtain maximum results in employee development, education and training programs are needed following job analysis so that employees know the objectives of the education and training they are carrying out.

Tua \& Simanjuntak (2015), defines education and training as part of the human investment to improve work abilities and skills to improve employee performance. Training is usually carried out with a curriculum that is adjusted to the needs of the position, given in a relatively short time, to equip someone with job skills. Likewise, in Nurasyiah's research, (2017) explained that education and training are efforts to develop apparatus resources, especially for professional improvement related to administrative skills and management (leadership) skills.

\section{Motivation}

According to Noor (2018), motivation is defined as something that can encourage someone to do something. Work motivation can come from outside the employee or from within the employee himself. Work motivation is a person's mental attitude or condition where the person feels moved to do a job that is assigned to him so that it can affect the ability and ability of employees to do the job. Motivation is also an important factor in contributing to efforts to encourage someone to work better in achieving the expected goals. With high work motivation in employees, it is hoped that they will love their work more. Work motivation is a condition or condition that encourages, stimulates, or moves a person to perform a work task that is mandated to him so that he can 
achieve his organizational goals. In the research of Pharisees (2020) motivation is a desire that arises from within a person or individual because it is inspired, encouraged, and driven to carry out activities sincerely, happily, and sincerely so that the results of the activities he does get good and quality results. (Afandi, 2018).

According to Greenberg and Baroon in Wibowo (2014), motivation is a series of processes to generate, direct and maintain human behavior towards achieving goals. Meanwhile, according to Ridhotullah and Jauhar (2015), motivation is a condition or energy that moves the employee who is directed or aimed at achieving the goals of the company organization. Professional and positive employee attitudes towards work situations strengthen work motivation to achieve maximum performance. According to Mangkunegara in Julianry et al., (2017) motivation is an impulse that appears in a person both because of internal and external factors that move him to do something to achieve goals. Motivation will provide opportunities for employees to increase employee passion and morale (Dewi and Laras, 2014).

\section{Knowledge Sharing}

According to Subagyo in Wahyuni and Kistyanto (2013) knowledge sharing is a method or one of the steps in knowledge management that are used to provide opportunities for members of a group, organization, agency, or company to share their knowledge, techniques, experiences, and ideas. to other members. Knowledge sharing according to Lumbantobing (2011) is a process that is carried out systematically in obtaining knowledge, distributing, and disseminating multidimensional knowledge from one person to another, or from organization to another through various media and methods.

According to the definition of Knowledge Sharing by Hooff and Ridder in Aristanto (2017), it is the process by which individuals exchange their knowledge (Tacit Knowledge and Explicit Knowledge). This activity is closely related to increasing the ability of individuals to innovate. Capability or ability in innovation, namely the ability to adapt, integrate and reconfigure all skills, functional competencies, and resources. Knowledge sharing activities include sharing experiences and knowledge, which will assist individuals in solving work problems based on existing experiences. Likewise, by sharing this knowledge, individuals will get more work knowledge to improve the effectiveness and efficiency of the work process. Increased Knowledge Sharing activities will affect increasing individual performance. (Wening, 2016).

Knowledge sharing has an important role in increasing individual competence in organizations because, through knowledge sharing, tacit and explicit knowledge can be disseminated, implemented, and developed by Mardlillah \& Rahardjo (2017).

Trivellas et al., (2015) revealed that a knowledgesharing culture can develop new general competencies in individuals or sharpen existing competencies, such as creating new ideas, communicating, interpersonal relationships, prioritizing things, creativity, planning, problem-solving, and team working. Management problems that often occur are precisely due to the lack of information needed by employees to carry out their duties. The application of knowledge sharing is expected to meet the information and knowledge needs of employees to carry out their duties properly.

Lumbantobing (2011) states that knowledge sharing is a systematic process of sharing and distributing knowledge from one party to another who is in need, through various methods and media. Knowledge sharing that occurs in organizations can be divided into two, namely tacit knowledge sharing and explicit knowledge sharing.

If knowledge sharing can be implemented properly, it can improve employee and organizational performance, because knowledge sharing will be able to produce employees who have good knowledge, so that they will be able to produce products and technology that are not easily imitated, unique, and have a long-lasting competitive advantage. (Zannah, 2013 in Andra \& Utami's 2018 research). Tobing (2011) states that through knowledge sharing, there will be maximum exploitation of knowledge. In addition to exploiting knowledge optimally, knowledge sharing can also open up opportunities to explore knowledge to gain or create new knowledge.

\section{Performance}

According to Mangkunegara in Wijaya et al., 2018) that employee performance is the result of work in quality and quantity achieved by an employee in carrying out his duties following the responsibilities assigned to him. According to Moeheriono, (2012) in Widayati's research, et al., (2020) performance is a description of the level of achievement of the implementation of an activity program or policy in realizing the goals, objectives, vision, and mission of the organization as outlined in the strategic planning of an organization.

According to Sedarmayanti (2017), performance refers to the notion of behavior as a set of behaviors that are relevant to the goals of the organization or organizational unit where people work. Performance is what people do and can observe. Factors that affect the high performance and low performance of an employee are of course determined by factors that influence it either directly or indirectly. According to Ekhsan, (2019) increasing the overall performance of employees in an organization will improve the smoothness of the work process, so that it will make it easier to achieve the goals of the organization concerned. Performance greatly affects the quality of a company, where performance determines the level of success of the running of a company from year to year which is produced by human resources who own the company according to predetermined work standards (Farisi et al., 2020). 


\section{(C) Center for Promoting Education and Research (CPER) USA}

WWW.cpernet.org

\section{Hypothesis}

Based on the subject matter and the above thought framework, the researchers formulated the following hypothesis:

H1: Education and Training has a positive and significant effect on Employee Performance

H2: Motivation has a positive and significant effect on employee performance

H3: Knowledge Sharing has a positive and significant effect on Employee Performance

\section{METHOD}

In this study, the authors used a causal research design. Causal research is a study that looks for a relationship between one variable and another variable that has a causal relationship. The research was conducted at a company engaged in the telecommunications sector in BSD Tangerang. The reason for choosing the object of research is because telecommunications companies have an important role, especially for society in communicating, and this company is also required to be ready for changes in the era of technology that is constantly changing to be more sophisticated, for this an organization like this requires an organization that is constantly learning, so that research on organizational learning is important. This research takes time from December 2020 to June 2021.

\section{Population and Research Sample}

The population in this study were all 188 employees of PT Telkom Akses BSD, using the Slovin formula with an error rate of 5\%, the total sample was 127 people. Sampling used purposive random sampling with the consideration that this company is the largest in the field of telecommunications services in Tangerang.

\section{Method of collecting data}

The method of collecting data in this research is through a questionnaire to determine the performance of the employees of PT. Telkom Access BSD. According to Sugiyono (2017), a questionnaire is a data collection technique that is carried out by giving a set of questions or written statements to respondents to answer. The questionnaire is an efficient data collection technique if the researcher knows exactly which variables to measure and knows what can be.

\section{Method of Analysis}

The data analysis method used in this research is the Component or Variance Based Structural Equation Model where the data processing uses the Partial Least Square (Smart-PLS) version 3.0 PLS program. PLS (Partial Least Square).

\section{RESULTS AND DISCUSSION}

\section{Hypothesis Testing Results (Estimated Path Coefficient)}

The estimated values for the path relationships in the structural model must be significant. The significance value of this hypothesis can be obtained by the bootstrapping procedure. Seeing the significance of the hypothesis by looking at the value of the parameter coefficient and the value of the T-statistic significance in the algorithm bootstrapping report. To determine whether it is significant or not, it is seen from the T-table at alpha $0.05(5 \%)=1.96$, then the T-table is compared with the T-count (T-statistic).

Table 1. Hypothesis Testing Results

\begin{tabular}{llllll}
\hline & $\begin{array}{l}\text { Original } \\
\text { Sample }\end{array}$ & $\begin{array}{l}\text { Standard } \\
\text { Deviation }\end{array}$ & $\begin{array}{l}\text { T- } \\
\text { Statistics }\end{array}$ & $\begin{array}{l}\text { P } \\
\text { Values }\end{array}$ & Information \\
\hline $\begin{array}{l}\text { Knowledge sharing } \\
\text { Employee performance }\end{array}$ & 0.640 & 0.114 & 5.603 & 0.000 & $\begin{array}{l}\text { Positive - } \\
\text { Significant }\end{array}$ \\
$\begin{array}{l}\text { Work motivation } \rightarrow \\
\text { Employee performance }\end{array}$ & 0.377 & 0.126 & 2.985 & 0.001 & $\begin{array}{l}\text { Positive } \\
\text { Significant }\end{array}$ \\
$\begin{array}{l}\text { Education and training } \rightarrow \\
\text { Employee performance }\end{array}$ & 0.301 & 0.123 & 2.439 & 0.002 & $\begin{array}{l}\text { Positive - } \\
\text { Significant }\end{array}$ \\
\hline
\end{tabular}

Source: Output PLS, 2021 

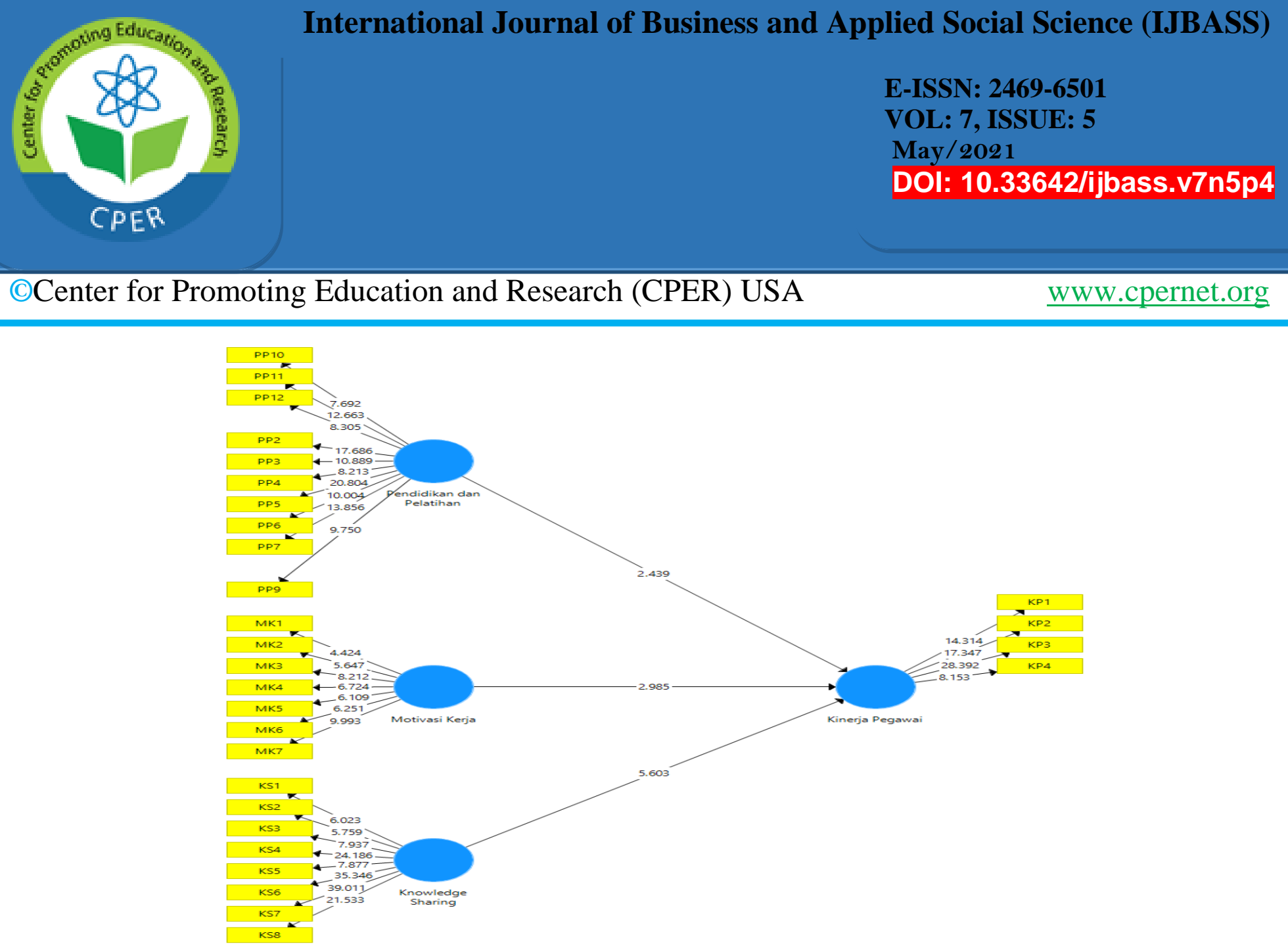

\section{Results and Discussion}

a. The effect of education and training on employee performance

Based on the hypothesis testing in this study, the Tstatistic value was 5.603, the original sample value was 0.640 , and the P-value was 0.000. The T-statistic value is greater than the T-table value of 1.96, the original sample value shows a positive value, and the P-value shows less than 0.05 , these results indicate that education and training have a positive and significant effect on employee performance.

The relationship between education and training and employee performance affects each other, where it is assumed that education and training are a response to an organization's needs. This is in line with the thinking of Sudiro (2009), which states that one way to improve the quality of an organization's human resources is through planned and systematic education and training programs. In other words, the importance of education and training in organizations is the improvement of employee performance which includes supporting knowledge and skills, as well as shaping the attitudes of each employee as desired by the organization.

Regarding research on the effect of Education and Training on employee performance, there is a positive and significant influence between the two. This is supported by research conducted by Tiara and Mulyadi (2005), Saputra, Siswidiyanto and Sukanto (2013), Nitta (2013).

\section{$b$. The effect of work motivation on employee performance}

Based on the hypothesis testing in this study, the Tstatistic value was 2,985, the original sample value was 0.377 , and the P-value was 0.001 . The T-statistic value is greater than the T-table value of 1.96, the original sample value shows a positive value, and the $\mathrm{P}$-value shows less than 0.05 , these results indicate that work motivation has a positive and significant effect on employee performance.

Work motivation has a relationship with employee performance. The role of work motivation can be explained as follows: high ability and support will also provide good diversity in the form of better (productive) productivity. If motivation is low and ability is high, there will be a dilemma about what the goals of the organization are and what the role of employees is, as well as the benefits for employees. If motivation is high but the ability is low, training for employees is needed. The situation will get worse if the motivation is low and the ability is low, the productivity will also below.

This is supported by research conducted by Dewanto (2011), Apriliana (2011), Adi (2012), Cahaya (2015), Dwi, Eko, Swasto (2015), and Arfan (2013) which state the same results that Motivation has a positive and significant effect on employee performance.

\section{c. The influence of knowledge sharing on employee performance}

Based on the hypothesis testing in this study, the Tstatistic value was 2.439 , the original sample value was 0.301 , and the P-value was 0.002 . The T-statistic value is greater than the T-table value of 1.96 , the original sample value shows a positive value, and the P-value shows less than 0.05 , these results indicate that knowledge sharing has a positive and significant effect on employee performance.

Through knowledge sharing, there will be maximum exploitation of knowledge. The use of knowledge that spreads to all members of an organization or all units within a 
company is, of course, far more optimal than the exploitation of knowledge carried out by certain individuals or certain units. The optimal utilization of certain organizational knowledge or competencies will increase the competitiveness of that company. In addition to exploiting knowledge optimally, knowledge sharing can also open up opportunities to explore knowledge to gain or create new knowledge. The knowledge-sharing approach from an innovation perspective or exploratory knowledge sharing is expected to become a trend of knowledge sharing in the future.

With the existence of a culture of knowledge sharing like this, the Treasury Bureau of the Ministry of Communication and Information Technology of the Republic of Indonesia can quickly find out about the latest developments and can adapt to changes in the environment that are felt to be getting faster. Achieve the success of knowledge management in the organization requires support from internal parties, namely employees in the organization. Good knowledge management can improve employee performance, namely through knowledge sharing, so that company performance will indirectly increase and have a competitive advantage. This is supported by research conducted by Memah, Jhonly, and Gerson (2017) and Boedi prasetya and Setiadi (2014) who state that there is the same result that Knowledge Sharing has a positive and significant effect on employee performance.

\section{CLOSING}

\section{Conclusions}

Based on the results of the analysis and discussion of the influence of Education and Training Motivation and Knowledge Sharing on Employee Performance, the following conclusions can be drawn:

1. Education and Training has a positive and significant effect on employee performance, meaning that Education and Training can be used to predict the increase and decrease in employee performance, the higher Education and Training, the employee performance will increase and vice versa.

2. Motivation has a positive and significant effect on employee performance, meaning that motivation can be used to predict the increase and decrease in employee performance, the higher the motivation, the higher the employee's performance, and vice versa.
3. Knowledge Sharing has a positive and significant effect on employee performance, meaning that knowledge sharing can be used to predict the increase and decrease in employee performance, the higher the knowledge sharing, the higher employee performance, and vice versa.

\section{Suggestion}

It is hoped that the company will pay more attention to the Knowledge Sharing program to get results, namely increasing the knowledge and skills of employees and in the end, it will improve employee performance. In addition, companies must develop a culture for sharing information and knowledge among employees, such as holding regular sharing sessions.

It is hoped that the company can increase employee motivation by providing rewards and punishment. Giving sanctions to those who are often late or rewarding exemplary employees who always obey company rules can increase motivation and ultimately improve employee performance. The purpose of giving rewards and punishment is to maintain the motivation of employees to get used to working with targets.

It is hoped that companies can maintain and improve Education and Training. This increase is not only in terms of quantity, but there must be an increase in quality. This is because the increase in abilities and skills cannot be felt and experienced by all employees. After all, only some employees are serious about doing and attending education and training while the rest are only for increasing positions or positions with the training and education certificates.

In connection with this research has limitations in conducting research, it is recommended for future researchers who want to research related variables contained in this study, namely Education and Training, motivation, Knowledge Sharing, and employee performance. So that further research can develop other variables such as compensation, satisfaction, work stress, and workload so that it can be used as a reference for researching variables that have never been done or using other research objects and by increasing the number of respondents in different research objects.

\section{Reference}

Abdullah, M. (2014). Manajemen and Employee Performance Evaluation. Aswaja Pressindo

Afandi, P. (2018). Human Resource Management. Pekan Baru: Zanafa Publishing.

Amalia, S. \& Fakhri, M. (2016). The effect of work Motivation on Employee Performance at PT. Gramedia Asri Media branch Emerlad Bintaro. Journal Computech \& Bisnis, 10 (2): 119- 127.

Andra, R. S., \& Utami, H. N. (2018). The influence of knowlage sharing on employee perfomance (studies on employee PT Bank Rakyat Indonesia branch Malang Kawi). Journal Administrasi Bisnis, 61(2), 30-37. 
Andria, V. dan E. Trisyulianti. (2016). Knowledge Management Implementation and Its Impact on Organizational Performance at PT Telekomunikasi Indonesia, Tbk. Journal Manajemen and Organization 2(2): 154. https://doi.org/ 10.29244/jmo.v2i2.14204.

Anggapraja, I. T. (2016). The Effect of Knowledge Management Application and Human Resource Development on Employee Performance of PT Telkom Tbk. (Explanatory Survey Study on Human Capital Management Unit Employees of PT Telkom Tbk.). Management Applications Journal 14(1): 140-146. https://doi.org/10.18202/jam23026332.14.1.15

Arfan Aruan, D. (2013). The influence of job training and motivation on the performance of employees of PT. Sucofindo (Persero) Surabaya. Journal of Management Science (JIM), 1(2).

Aristanto, D. B. (2017). The Influence of Knowledge Sharing on Individual Innovation Capability and Employee Performance (study at PT. PLN (Persero) the main unit of North Sulawesi development). EMBA Journal: Journal of Economic Research, Management, Business and Accounting,5(2).

Dewi Sri K, Laras T. (2014). The influence of training, work motivation and work environment on the performance of the employees of the Student Cooperative (KOPMA) in Sleman Regency. Journal of Business and Economics 5 (1): 48-72

Ekhsan, M. (2019). The Influence of Motivation and Work Discipline on Employee Performance. Optimal: Journal of Economics and Entrepreneurship, 13 (1), 1-13.

Elizar, E., \& Tanjung, H. (2018). Effect of Training, Competence, Work Environment on Employee Performance. Maneggio: Scientific Journal of Master of Management, 1 (1), 46-58.

Farisi, S., Irnawati, J., \& Fahmi, M. (2020). The Influence of Motivation and Work Discipline on Employee Performance. Journal of Humanities: Journal of Social Sciences, Economics and Law, 4 (1), 15-33.

Ghozali, Imam. (2014). Partial least squares concepts, methods and applications using the PLS 4.0 Warp Program, Diponegoro University Publishing Agency, Semarang

Hardjanto, Imam. (2012). Apparatus Resource Management (MSDA).Malang

Hasibuan, M. S., \& Hasibuan, H. M. S. (2016). Human Resource Management. Earth Literacy. Heriyanto, \& Hidayati, S.N, (2016). The Influence of Work Motivation and Work Discipline on Employee Performance, Maksipreneur Journal, 6 (01), 67-76.

Hidayat, W. (2020). Payroll System as a Moderator of Work Motivation and Teacher Certification of Teacher Performance(Studi Pada Pondok Modern Muhammadiyah Paciran Lamongan) (Doctoral dissertation, University Muhammadiyah Malang).

Indriapati, A., Razak, M., \& Hidayat, M. (2020). The Influence of Education and Training, Work Motivation and Work Culture on Employee Performance at the SecretariatDprd Kabupaten Pinrang. Nobel Management Review, 1(1), 101-111.

Jatmiko, E. D. (2015). The Effect of Work Motivation and Organizational Commitment on Employee Performance (Studies on Factory Compartment Employees II PT. Petrokimia Gresik). Journal Administrasi Bisnis, 21(1).

Julianry, A., Syarief, R., \& Affandi, M. J. (2017). Effect of training and motivation on employee performance and organizational performance of the Ministry of Communication and Information Technology. Journal of Business and Management Applications (JABM), 3(2), 236-236.

Kristine, E. (2017). The Effect of Job Satisfaction and Organizational Commitment on Performance Through Outsourcing Employees' Work Motivation at PT. Mitra Karya Jaya Sentosa. Journal EKSEKUTIF, 14(2).

Kuzu, Ö. H. dan D. Özilhan. (2014). The Effect of Employee Relationships and Knowledge Sharing on Employees' Performance: An Empirical Research on Service Industry. Procedia-Social and Behavioral Sciences, 109, 1370-1374. https://doi.org/10.1016/j.sbspro.2013. 12.639

Kwahk, K. Y. dan D. H. Park. (2016). The effects of network sharing on knowledge-sharing activities and job performance in enterprise social media environments. Computers in Human Behavior, 55, 826-839.

https://doi.org/10.1016/j.chb.2015.09.044. Lumbantobing, P. (2011). Community Based Knowledge Sharing

Management Bandung: Knowledge Manajement Society Indonesia.

Mangkunegara, A. P. (2013). Corporate Human Resource Management. Bandung: PT. Remaja Rosdakalya.(translated from Indonesian: Human Resource Management of the Company Bandung: PT. Remaja Rosdakalya). 
Mardlillah, A. I., \& Rahardjo, K. (2017). The Influence of Knowledge Sharing on Individual Competencies and Employee Performance (Studies on Non-medical Employees RS Lavalette Malang). Journal Administrationi Business, 46(2), 2836.

Marifa, N., Kasim, K. T., \& Lukiana, N. (2018). Effect of Training and Work Motivation on Employee Performance CV. Langgeng Makmur Bersama at the Regency lumajang. Jobman: Journal of Organization and Bussines Management, l(2), 196-205.

Memah, L., Pio, R. J., \& Kaparang, S. G. (2017). The Influence of Knowledge Sharing on Employee Performance at Bank Indonesia Representative Office, North Sulawesi Province. Journal Administration Business (JAB), 5(002).

Muogbo, U. S. (2013). The influence of motivation on employees' performance: a study of some selected firms in Anambra State. AFRREV IJAH: An International Journal of Arts and Humanities, 2(3), 134-151.

Nasfi, N. (2020). The Influence of Leadership and Career Development on Employee Performance of the Umkm Cooperative Office of West Sumatra Province. Al-Fikrah: Journal of Educational Management, 8 (1), 11-28.

Ningrum, W. (2013). The Effect of Education and Training on Employee Performance (Studies on Employees Joint Operating Body Pertamina-PertoChina East Java). Journal Administration Business, 6(2).

Noor,.(2018). Analysis of Employee Performance Influenced by Motivation, Compensation and Leadership Style Variables at the KPU Secretariat Regency Pulang Pisau and Regency Kapuas, Journal Administration and Management, 2 (01), 4161.

Nurasyiah, H. (2017). Influence (Education and Training) on Employee Performance atBANK BPR Rokan Hulu. Cano Ekonomos, 6(1), 71-82.

Ozlen, M. K. (2015). Knowledge Sharing Behaviour of Bosnian Enterprises. Journal of Accounting and Management Information Systems, Faculty of Account-ing and Management Information Systems, The Bucharest University of Economic Studies, 14(3): 575-590

Pakpahan, E. S. (2014). The Influence of Education and Training on Employee Performance (Study at City Regional Civil Service Bodies Malang). Journal Administration Public, 2(1), 116- 121.

Pituringsih, E. (2019). Factors Affecting the Readiness of Application of Accrual-Based Sap and Performance Accountability of Government Agencies (Empirical Studies in District Government Dompu). Journal Actual accounting, 3(1), 62-73.

Puspitasari, R. (2014). The Effect of Work Motivation and Job Training on Employee Performance at the Primary Tax Office Magelang. Skripsi. Fakultas Economi University Negeri Yogyakarta.

Ridhotullah S. dan Mohammad Jauhar. (2015). Intrudaction To Management. Jakarta: Prestasi Pustakaraya

Rose, R. C., N. Kumar, danO. G. Pak. (2011). The effect of organizational learning on organizational commitment, job satisfaction and work performance. The Journal of Applied Business Research, 25(6): 55-56

Rozi, V. F., \& Anggraini, M. S. (2019). The Effect of Education and Training on the Performance of Pharmacist Assistants in Pharmacy Installations Dr. M. Yunus Bengkulu. Avicenna: Journal scientific, 14(02), 1-5.

Rumijati, A. (2020). The Role of Knowledge Sharing and Motivation on the Influence of Learning Organization on Employee Performance. EQUITY (Journal of Economics and Finance), 4(2), 226-245.

Sakti, R. T., \& Mulyadi, M. (2015). Implementation of Education and Training in Improving the Performance of Civil Servants (PNS) at the Provincial Education and Culture Office Bengkulu. Mimbar: Journal of Social and Political Research, 4(2), 37-48.

Sanjiwani. (2015). Accountability of Village Fund Management (Case Study of Village Fund Allocation Management in Kalisat District, Regency Jember 2013 ${ }^{\text {th }}$. Published. Journal of Accounting, University of Jember.

Sedarmayanti, S., \& Safer, G. Y. (2016). The Effect of Work Motivation on the Performance of Primary School Teachers in the One Village Cluster Neglawangi Distritc Kertasari Regency Bandung. Journal of Administrative Sciences: Media for the Development of Administrative Sciences and Practice, 13(3), 501-524.

Sedarmayanti. (2017). HR Planning and Development. Bandung: Refika Aditama

Selong, I. (2019). The Effect of Education and Training (Diklat) on Employee Performance at the Department of Agriculture and Animal Husbandry. Thesis, Muhammadiyah University of Makassar 
Setiawan, K. C. (2015). The influence of work motivation on the performance of the executive level employees in the operations division of PT. Pusri Palembang. Psychic: Journal of Islamic Psychology, 1(2), 43-53.

Shen, J., \& Zhang, H. (2019). Socially responsible human resource management and employee support for external CSR: roles of organizational CSR climate and perceived CSR directed toward employees. Journal of Business Ethics, 156(3), 875888.

Sugiyono. (2017). Educational Research Methods (Quantitative Approaches, Qualitative and R \& D). Publisher CV.Bandung. Alfabeta.

Sunyoto, Danang. (2014). Basic Concepts of Marketing Research \& Consumer Behavior. Yogyakarta. CAPS.

Syahputra, I., \& Jufrizen, J. (2019). The Influence of Training, Promotion, and Job Satisfaction on Employee Performance. Maneggio: Scientific Journal of Master of Management, 2(1), 104-116.

Trivellas, P., Akrivouli, Z., Tsifora, E., Tsoutsa, P. (2015). The Impact of Knowledge Sharing Culture on job Satisfaction in Accounting Firm with Mediating Effect of general Competencies. E-journal Procedia Economic and Finance Elsevier. 19: $238-247$

Trang, N. I., S. A. Armanu, danNoermijati. (2013). Organizational Commitment as Mediation Variable Influence of Work Motivation, Leadership Style and Learning Organization to the Emplo-yees Performance. IOSR Journal of Business and Management (IOSR-JBM), 7(2):12-25

Tua, H., \& Simanjuntak, M. (2015). The Effect of Education and Training on Improving the Performance of Agricultural Extension at the Implementing Agency for Agricultural, Fisheries and Forestry Extension (Bp4k) Regency Toba Samosir (Doctoral dissertation, Riau University).

Vrizka, V., \& Silvianita, A. (2016). The Influence of Knowledge Sharing on Organizational Performance at the Environmental Agency of North Sumatra Province. eProceedings of Management, 3(2).

Wahyuni, Rista Ramadhan Tri dan Kistyanto, Anang. (2013). The Influence of Knowledge Sharing on Department Performance Through Service Innovation. Journal of Management Science, 1 (4),

Wang, S. dan N. Wang. (2012). Knowledge sharing, innovation, and firm performance. Expert Systems with Application, 39(10): 8899-8909

Wening, Nur \& Harsono, Mugi. (2016). Relationship between knowledge sharing to individual Performance. International Journal of Research in Business Management, 4 (1): 67 - 78.

Wibowo., (2014). The Effect of Compensation and Work Motivation on Employee Performance (Studies on PT.Internusa employees). Journal Management, 2(10): 120-127.

Wibowo, A. (2019). The Influence of Organizational Commitment and Work Motivation on Employee Performance at the Central Lampung District Health Office. Simplex Journal, 2(3).

Widayati, C., \& Triana, R. (2020). The Effect of Job Satisfaction and Organizational Commitment on Employee Performance. Journal of Managerial Perspectives and Entrepreneurship (JPMK), 1(1), 15-25.

Wijaya, P. H., Widayati, C. C., \& Rahmayanti, C. (2018). The Influence of Situational Leadership Style, Organizational Culture and Compensation on Performance. Journal Economi, 23(3), 319-333.

Yousef Obeidat, B., A. Bahjat Abdallah, N. Osama Aqqad, A. H. O. M. Akhoer- shiedah, dan M. Maqableh. (2017). The Effect of Intellectual Capital on Organizational Performance: The Mediating Role of Knowledge Sharing. Communications and Network 09(01): 1-27. https://doi.org/10.4236/cn.2017. 91001.

Zaeid, A. N., G. Hussein, dan M. Hassan. (2012). The Impact of Job Satisfaction and Knowledge sharing on Employee Performance. Journal of Resources Development and Management 21:2422-8397. 